\title{
ECONOMY AND MANAGEMENT
}

UDC 323.2:314/316

O.P. Vasylchenko, Dr. Sc. (Jurid.), Assoc. Prof., orcid.org/0000-0002-4464-3708,

O. S. Lotiuk, Dr. Sc. (Jurid.), Assoc. Prof., orcid.org/0000-0001-7119-754X,

N. Y. Gut, Cand. Sc. (Jurid.), Assoc. Prof., orcid.org/0000-0002-6984-6245
DOI: $10.29202 /$ nvngu/2018/20

Taras Shevchenko National University of Kyiv, Kyiv, Ukraine, e-mail: mfkoorg@gmail.com

\section{CIVIL SOCIETY AS THE SUBJECT OF FORMATION OF STATE POLICY IN THE SPHERE OF SUBSOIL USE AND PROTECTION}

Purpose. To reveal the peculiarities of the constitutional principles of equal partnership of the civil society and the state in formation of state policy of use and protection of mineral resources as objects of property of the Ukrainian people. To analyse the interaction of civil society and state, to formulate the controlling functions of civil society institutions in mineral resources usage, as well as to determine the forms of participation and control of civil society institutions in the use and protection of mineral resources.

Methodology. The authors have applied the structural and functional method, as well as the comparative legal method, the historical retrospective method, the formal dogmatic method, the concrete sociological method. The authors accentuate the necessity of using the institutional research method.

Findings. The authors have considered the development of the civil society in Ukraine at the beginning of the $21^{\text {st }}$ century, drawing a conclusion that the civil society development is based on an essentially modified system of constitutional values. Every victory gained by the civil society over the state authorities' inaction is followed by new principles of interaction of the civil society and the state. It is suggested that development of the state policy in use and protection of mineral resources should be based on the anthropocosmism principle being transformed, in modern science terms, into the Mental Universe paradigm. In conformity with the anthropocosmism principle, the state is to act solely for the benefit of the man of the future, by way of all-round assurance of priority of his rights, freedoms and lawful interests in public administration activity. The property, mineral resources in particular, cannot be used to the damage of man and society. The authors have determined that the granting of supervisory powers to civil society institutions stipulates an opportunity of influencing the state policy, with the goal of protecting the lawful interests of the people as a mineral resources owner.

Originality. There has been developed a system of forms for participation of civil society institutions in the use and protection of mineral resources. The forms of participation include: citizens' appeals, preparation and initiation of adoption or repeal of statutory acts, peaceful meetings to influence the decision making by authorized bodies of public administration, professional representation of society's interests in public authorities. There have been singled out basic forms of control by the civil society and its institutions over the state authorities and local self-government bodies: expertise of efficiency of decisions made by public administration; training of consultancy and expert bodies and commissions created in cooperation with the public administration, with the goal of considering the public opinion in formation of state policy in the use and protection of mineral resources; submission of expert suggestions to public administration bodies.

Practical value. The results obtained allow determining the efficient forms of participation and control of civil society and its institutions in exercising the rights of the mineral resources owner, in particular ownership, use and disposal of mineral resources. Civil society institutions, in the name of the Ukrainian people, exercise the rights of the mineral resources owner, within the limits stipulated by the Constitution and the Laws of Ukraine. At the same time, they provide for the social control over the activity of state authorities and local self-government bodies. Such a complex and systemic approach to the role of civil society institutions leads to strengthening their influence on making socially important decisions in the use of mineral resources, as well as protection against illegal infringement by the state and other subjects. It is proposed to consolidate the approach by adding the following statement to Article 13 of the Constitution of Ukraine: "The civil society and the state of Ukraine are equal partners in assuring and protecting the rights of the people of Ukraine as the owner of the land, its mineral, water and other natural resources".

Keywords: civil society, anthropocosmism principle, use and protection of mineral resources, natural resources 
Introduction. Ukraine is going through the first stages of civil society formation. If compared to other European states, Ukraine's independence time, which is a little less than thirty years, is a rather short period in the history of culture. Ukraine has not yet completed its state-forming processes: de-communisation of dominant ideas, ideals and values; formation of the national idea; strengthening of independent branches of power: executive, legislative and judicial, and others [1]. Thus, Valentina Voronkova has considered the peculiarities of civil society development in Ukraine in the context of social and philosophical discourse, as a paradigm, a theory, a concept and a construct. V. Voronkova has developed a hypothesis in which the civil society institutions in Ukraine are viewed as a complicated social structure, where the subject-object interaction has just started forming. According to V. Voronkova, the only possible base for civil society formation in Ukraine is its middle class. As V. Voronkova writes, only the middle class is able "to assure efficient self-regulation and an object's dynamic development" [2].

In this research, the authors will suggest their vision of perspective development of the civil society in Ukraine, as well as consider various participations of civil society institutions in the use and protection of mineral resources. The authors will prove the importance and necessity of civil society participation in state policy formation as to the use and protection of mineral resources. Participation of the civil society in protecting and using the country's natural resources guarantees stable development of both the society itself and its institutions.

Analysis of the recent research. There are various approaches to civil society formation in Ukraine, for example, through the constitutional paradigm of a political nation studied by Gregory Berchenko [3]. Another approach - a cross-disciplinary one - is used by the scientists of the National Institute for Strategic Research. The Institute's authoring teams carry out the cross-disciplinary analysis of the society's development in Ukraine in yearly analytical reports. The researchers of the Institute use the cross-disciplinary analysis to suggest their view on the stages of formation and development of the Ukrainian society. The reports deal with the processes of the civil society's institutional development; peculiarities of formation and implementation of various ways of interaction of the state authorities with non-governmental organizations. They also characterize the social sector and investigate social initiatives, forms and practices of self-organization of the Ukrainian people [4]. One of the latest studies generalizing the existing approaches to civil society development as an object of scientific research is the article by S. Volynets [5]. S. Volynets states that not until 2010 did the ideas of the civil society's development in Ukraine get proper consideration as a permanent element of state policy. S. Volynets admits that actually only twenty years after Ukraine's gaining its independence, there appeared a vector of strategic development of state power institutions. Ukraine has made its final choice towards the European development which brought the crucial changes in legislative, executive and judicial powers. Therefore, since 2010 the formation of the civil soci- ety in Ukraine has become the leading subject of the scientific research. At present, the research into peculiarities of the Ukrainian society's development is supervised by the state authorities, academic institutions and international organizations.

Presentation of the main research. The subject analysed in this article is characteristic features of development of a society as a subject of state policy formation in the use and protection of mineral resources. The modern legislation is based on the following idea: to preserve and enrich the country's natural resources, the civil society should directly influence the state policy in use and protection of natural resources. Their rational use and protection guarantee the stable development of society and country.

The authors fully agree with the idea enriched in the Law of Ukraine; however, it is suggested to specify it using the anthropocosmism principle. According to the authors, it is the anthropocosmism principle the state policy in use and protection of mineral resources should be based on. The anthropocosmism principle was scientifically introduced and reasoned by the outstanding Ukrainian academicians Volodymyr Vernadskyi and Mykola Kholodnyi. The modern interpretation of Volodymyr Vernadskyi's and Mykola Kholodnyi's views is set forth in the research by Oleh Bazaluk [6]. The key feature of the anthropocosmism principle developed by the geologist and mineralogist Volodymyr Vernadskyi and the biologist Mykola Kholodnyi in the first half of the $20^{\text {th }}$ century, is man's appeal to the future, mostly to the cosmic future. Unfortunately, the modern scientific discourse tends to view the state policy in use and protection of mineral resources as the policy based on the "anthropocentrism principle", reasoning this choice by the fact that "anthropocentrism" is a policy for the benefit of man and society. In fact, the "anthropocentrism principle" has lost its significance as far back as the first half of the $20^{\text {th }}$ century. The academician M. Kholodnyi stated its inconsistence in his short work "A Darwinist's Ideas on Nature and Man" (1944), which was severely criticized in the USSR central communist periodicals. Instead of the communist ideology term "anthropocentrism", M. Kholodnyi introduced a new term "anthropocosmism" into scientific discourse. M. Kholodnyi believed that a human being's activity for his own benefit, like any "centrism", is fraught with self-isolation from the environment, global cataclysms and death of population. In principle, "centrism", including the "anthropocentrism" ("anthropos" meaning "man", if translated from Greek), is impossible in the open cycles of matter, energy and information, in other words natural environment. Volodymyr Vernadskyi and Mykola Kholodnyi proved that human future is possible only if a man treats natural resources basing on more reasonable and stable values. Oleh Bazaluk refers these values to philosophical traditions or Plato's line traditions [7, 8]. These values are based on the natural dependence of microcosm evolution (man and society) on macrocosm (evolution of the Universe). Actually, V. Vernadskyi and M. Kholodnyi discovered in the anthropocosmism principle an ontological link between man and cosmos, pointing out the fact that a man is open to cosmos and 
cosmic processes. In the modern sense, the anthropocosmism principle considers the sense of human life in ideals and values of the future, in correlation of evolution or co-evolution, of man and the Universe.

In the last twenty years, the anthropocosmism principle has transformed into a new paradigm of the Mental Universe, which is being actively mainstreamed into mass consciousness. As viewed by Bernardo Kastrup, "This new paradigm will necessarily entail some form of idealism: the notion that a universal mind is nature's sole fundamental entity, everything else being reducible to excitations of universal mind" [9]. The Mental Universe paradigm was suggested by the astrophysicist Richard Conn Henry in 2005. In the past ten years, it was proved in mathematics and astrophysics, having taken the leading position in the worldview philosophical discourse [10, 11].

The Mental Universe paradigm leads to reconsideration of the opportunities and importance of rational methods and materialistic outlook, respectively. For the purpose of our research, several effects are important.

Effect 1: material values lose their importance. In the Mental Universe, a man is viewed as a world of consciousness for which the main values are time and knowledge. This is the reason why we observe a largescale transformation of the system of constitutional values in highly developed countries of the world. One of the components of this large-scale transformation is the attitude of the civil society to the use and protection of mineral resources, all natural resources on the country's territory. The society refuses to view natural resources as raw materials, as a basic source of the country's economic and social development. It concentrates its efforts on creation and use of high technologies, considering mineral resources as a historical and cultural value but not as a source of income and welfare [12].

Effect 2: the Mental Universe paradigm considerably broadens the period of time for predicting the society's development. Modern highly-developed societies refuse to live for themselves, for the present, choosing the style of life which benefits future generations. Strategies of countries' development for 50 and 100 years have become the reality of today which predict the development peculiarities of society and its institutions. Highly-developed communities stop living for themselves and for satisfying their current needs. The meaning of the term "present" which is now understood in terms of the future but not of the past has changed. "Present" has become a time stage in consistent reaching of the future. It is this change that gives birth to a new attitude to natural resources: not to use everything for yourself, in the here and now, but to think over the question how such use will affect the life of future generations. What are the resources for generations of children, grandchildren and great-grandchildren to survive on?

Effect 3: the anthropocosmism principle and the Mental Universe paradigm suggest involving the civil society into world processes. A civil society is no longer viewed as a closed cultural enclave. A civil society is supposed to be integrated into globalization processes, with an opportunity to choose development strategies, goals and ideals. Modern realia allow for comparison and selection of the most acceptable ways of civil society development. In- structive in this way are the sample development strategies of China, Japan, South Korea and other countries. A society itself chooses the way of development and the ideal to follow. Politicians and politics only represent the civil society on the world arena. They concentrate in themselves the society's basic features, which visually demonstrate the chosen strategy of national development. It is the citizens and non-governmental social organizations that choose strategies of national and cultural development.

Thus, we have specified the base for state policy formation in the use and protection of mineral resources. In fact, this base has been effectively used in highly-developed world countries for several decades. The anthropocosmism principle and the Mental Universe paradigm enrich the opportunities of citizens and their organizations in rational use and protection of mineral resources opening new perspectives of resource development. Caring or wasteful attitude of the society to consumption of mineral, raw and energy resources is in fact determined by current and future goals of the country's development. With their activity and influence on the state-forming processes, citizens and non-governmental social organizations establish and enrich in the law the way of the country's development: a producer of mineral raw materials or a high technology producer. In the first case, the use of mineral raw material potential meets the requirements of the state and its citizens, brings the major part of currency income, and turns citizens into hostages of export prices for raw materials and minerals users. In the second case, citizens and their organizations are concentrated on developing human but not natural potential. This way leads to formation of opposite perception of the world: attitude to nature and its stores as a historical and cultural value.

The society fixes and passes the chosen development strategy to future generations through education. The modern education system allows integrating into crosscultural communication any society including the Ukrainian society being formed. Education opens opportunities to choose and use the experience of building-up both social institutions and the policy of use and protection of mineral resources in highly-developed countries [13]. This is precisely why the Ukrainian society first of all needs to select a strategy of the country's development in conformity with the historical and cultural traditions. Our viewpoint is that such choice should be in favour of development of a high-technology society but not the society considering minerals as a source of welfare. The selection of strategy of high-technology development, which is based on the anthropocosmism principle and the Mental Universe paradigm, is enriched in the Laws of Ukraine, and impressed upon the worldview of the Ukrainian people through education technologies. Possible integration of the Ukrainian society into modern world processes was considered by Serhii Rudenko [14], Denys Svyrydenko [15], Charles McGrath [16], Iryna Liashenko [17], and others.

We shall take look at the most reputable forms of participation of citizens and their organizations in highly developed countries as subjects of state policy formation in the use and protection of mineral resources. The 
use of the accumulated experience by the Ukrainian society will increase the control over the activities of state authorities and local self-government bodies, promoting the society's influence on making socially important decisions in the use and protection of mineral resources. Let us outline the following forms:

1. Citizens' appeals to state power institutions. The Law of Ukraine "On Citizens' Appeal" regulates the issues of practical realization by the Ukrainian citizens of rights stipulated by the Constitution of Ukraine.

2. Preparation and initiation of adoption or repeal of statutory acts regulating the state policy in the use and protection of mineral resources.

3. Organization of peaceful meetings to influence the decision making by authorized bodies of public administration.

4. Professional representation of the society's interests in public authorities.

Considering the civil society development in Ukraine in the early $21^{\text {st }}$ century, the authors point out the essential upgrade of the system of constitutional values. Every new victory of the civil society over the state authorities' inaction is followed by new principles of interaction of the civil society and the state. The 2004 Orange Revolution and the 2014 Revolution of Dignity fixed the European vector of the Ukrainian society's development. On the one hand, the European choice has accelerated de-communisation processes in Ukraine: rejection of communist ideals and elimination of communist ideology from all spheres of social life. On the other hand, to replace the communist ideas, ideals and values, there have come European values, including new opportunities of controlling the civil society's institutions in the use of mineral resources.

On January 1, 2013, the Law of Ukraine "On Civil Groups" came into effect. The new Law adopted by the Verkhovna Rada is three times as long as the previous Law of Ukraine "On Citizen Groups" which acted from June 1992. What is most important, the change in the name of the main law regulating the activity of social organizations reflects the real changes in the core of understanding of civil society institutions. In fact, there were legalized European values and approaches to understanding the civil groups, their formation and activity. Introduction of the Law into effect has brought great changes in regulation of citizens' activity, broadened the scope of authority of civil groups and simplified the registration procedures. The Law has introduced in Ukraine a new legal and organization base of rights for the citizens of Ukraine to the freedom of civil groups guaranteed by the Constitution of Ukraine and Ukraine's international agreements.

The Law has increased the control of the society and non-governmental organizations over the action of state authorities and local self-government bodies. Here we shall point out the basic forms of control:

1. Expertise of efficiency of decisions made by public administration.

2. Creation, in cooperation with the public administration, of consultancy and expert bodies and commissions to consider the public opinion as to formation of state policy in the use and protection of mineral resources.
3. Submission of expert suggestions to the public administration.

The granting of supervisory powers to civil society institutions stipulates an opportunity of influencing the state policy to protect the lawful interests of the people as a mineral resources owner.

Involvement of knowledge and experience of development of advanced countries into the development of the Ukrainian society provides for its high-quality growth. It also increases the development rate of state institutions, allowing them to determine the efficient forms of participation and control of citizens and their groups in exercising their rights as a mineral resources owner. The experience of highly developed countries in organizing the ownership, use and disposal of mineral resources is to become an essential source of formation of the state policy in mineral resources management. Civil society institutions, in the name of the Ukrainian people, exercise the rights of the mineral resources owner, within the limits stipulated by the Constitution and the Laws of Ukraine. At the same time, they provide for the social control over the activity of state authorities and local self-government bodies. Such a complex and systemic approach to formation of the society and social organizations leads to strengthening the citizens' influence on making socially important decisions in the use and protection of mineral resources against illegal infringement by politicians and other subjects. The authors consider it necessary to confirm the research results by adding the following statement to Article 13 of the Constitution of Ukraine: "The civil society and the state of Ukraine are equal partners in assuring and protecting the rights of the people of Ukraine as the owner of the land, its mineral, water and other natural resources".

Conclusions. In the present research, the authors have revealed the peculiarities of the constitutional principles of equal partnership of the civil society and the state in formation of state policy of use and protection of mineral resources as objects of property of the Ukrainian people. The authors have suggested that development of the state policy in use and protection of mineral resources should be based on the anthropocosmism principle, which is transformed, in modern science terms, into the Mental Universe paradigm. Basing upon the effects of the Mental Universe paradigm, the authors have analysed the interaction of the civil society and state. The analysis resulted in formulating the most efficient modern control functions of citizens and non-governmental social organizations in mineral resources usage, as well as forms of participation and control of civil society institutions in the use and protection of mineral resources.

\section{References.}

1. Bazaluk, O., 2016. Corruption in Ukraine: Rulers' Mentality and the Destiny of the Nation, Geophilosophy of Ukraine. Cambridge Scholars Publishing.

2. Voronkova, V., 2015. The Civil Society as a Paradigm, Concept and Social Construct Philosophical Discourse. Philosophy and Cosmology, 15, pp. 198-215.

3. Berchenko, G., 2014. Civil Society in Ukraine: Constitutional Aspects. Kharkiv: Yurayt. 
4. Korniyevskyi, O. A. and Rozumnyi, M. M., eds. 2015. The development of civil society in Ukraine: an analytical report. Kyiv: NISD.

5. Volynets, S. S., 2017. Development of civil society as an object of scientific research. Public administration aspects, 5(8-9), pp. 11-21. DOI: 10.15421/15201724.

6. Bazaluk, O., 2016. The Theory of Evolution: From a Space Vacuum to Neural Ensembles and Moving Forward. Cambridge Scholars Publishing.

7. Bazaluk, O., 2017. Plato's and Isocrates' Traditions in the Development of Educational Theories in the History of Culture. Annals of the University of Craiova Philosophy Series, 40(2), pp. 5-18.

8. Bazaluk, O., 2018. The Feature Transformations of the Basic Meanings of Greek Paideia in the Educational Theories in the Middle Ages. Schole, 12.1, pp. 243-258. DOI: 10.21267/AQUILO.2018.12.10428.

9. Kastrup, B., 2018. The Next Paradigm. Future Human Image, 9, pp. 41-51. DOI: 10.29202/fhi/9/4.

10. Kastrup, B., 2017. Making Sense of the Mental Universe. Philosophy and Cosmology, 19, pp. 33-49.

11. Kirsh, M., 2016. What in the World is Universe?: A Prime Example. Philosophy and Cosmology, 17, pp. 106-117.

12. Kieliszek, Z., 2018. National Identity as an Important Topic of the Research of the Man in the Future: "Opening" the Potential of the Fichtean Concept of National Identity. Philosophy and Cosmology, 20, pp. 83-91. DOI: 10.29202/phil-cosm/20/7.

13. Naumenko, R., 2017. Management for the Society of the Future: New Trends in the Training for Civil Servants in Ukraine. Philosophy and Cosmology, 19, pp. 117-125.

14. Rudenko, S., Sapenko, R., Bazaluk, O. and Tytarenko, V., 2018. Management Features of International Educational Projects Between Universities of Poland and Ukraine. Naukovyi Visnyk Natsionalnoho Hirnychoho Universytetu, 2, pp. 142-147. DOI: 10.29202/nvngu/2018-2/21. 15. Bazaluk, O., Svyrydenko, D. and Terepyshchyi, S., 2017. Structural-Functional Models of Integration and Reintegration of Ukrainian Educational Landscape. Naukovyi Visnyk Natsionalnoho Hirnychoho Universytetu, 5, pp. 163-168.

16. McGrath, Ch., 2018. Master Narratives of Ukrainian Political Culture. Future Human Image, 9, pp. 74-81. DOI: $10.29202 /$ fhi/9/7.

17. Liashenko, I. and Rudenko, S., 2018. The management features of the university preparatory department. Naukovyi Visnyk Natsionalnoho Hirnychoho Universytetu, 1, pp. 132-138. DOI: 10.29202/nvngu/2018-1/6.

\section{Громадянське суспільство як суб'єкт формування державної політики у сфері використання та охорони надр}

О. П. Васильченко, О. С. Лотюк, Н. Ю. Гуть

Київський національний університет імені Тараса Шевченка, м. Київ, Україна, е-mail: mfkoorg@gmail.com

Мета. Розкрити особливості конституційних принципів паритетного партнерства громадянського суспільства та держави у процесі формуван- ня державної політики у сфері використання та охорони надр як об'єктів власності українського народу. Провести аналіз взаємодії громадянського суспільства та держави, визначити контрольні функції інститутів громадянського суспільства у сфері використання надр. Визначити форми участі й контролю інститутів громадянського суспільства у сфері використання та охорони надр.

Методика. Автори використовували структурно-функціональний метод, а також порівняльноправовий, історико-ретроспективний, формальнодогматичний, конкретно-соціологічний методи. Автори наголошують на необхідності використання інституційного методу дослідження.

Результати. Автори розглянули розвиток громадянського суспільства в Україні на початку XXI століття й прийшли до висновку, що він відбувається на основі істотно модернізованої системи конституційних цінностей. Кожна здобута перемога громадянського суспільства над бездіяльністю органів державної влади супроводжується новими принципами взаємодії громадянського суспільства та влади. Запропоновано в основу державної політики у сфері використання та охорони надр закласти принцип антропокосмізму, що в сучасній науці трансформувався в парадигму Ментального Всесвіту. Згідно із принципом антропокосмізму держава повинна діяти виключно на благо людини майбутнього, шляхом усебічного забезпечення пріоритету його прав, свобод i законних інтересів у процесі діяльності публічної адміністрації. Власність, а саме, надра, не можуть бути використані на шкоду людині й суспільству. Автори визначили, що в основі надання контрольних повноважень інститутам громадянського суспільства належить можливість їх впливу на державу з метою захисту законних інтересів народу як власника надр.

Наукова новизна. Розроблена система форм участі інститутів громадянського суспільства у сфері використання та охорони надр. До форм участі віднесені: звернення громадян, підготовка та ініціювання прийняття або скасування нормативно-правового акту, проведення мирних зборів, мітингів з метою впливу на прийняття рішень уповноваженими органами публічної адміністрації, здійснення професійного представництва інтересів громадськості в органах публічної влади. Виділені основні форми контролю громадянського суспільства, його інститутів органів державної влади та органів місцевого самоврядування: проведення експертизи ефективності прийнятих рішень публічною адміністрацією; утворення спільних з публічною адміністрацією консультативно-дорадчих і експертних органів, комісій 3 метою врахування громадської думки під час формування державної політики у сфері використання та охорони надр; надання органам публічної адміністрації експертних пропозицій.

Практична значимість. Використання отриманих результатів дозволяє визначити ефективні форми участі й контролю громадянського суспільства та його інститутів у процесі реалізації прав власника надр, а саме: володіння, користування й розпоря- 
дження надрами. Інститути громадянського суспільства від імені українського народу здійснюють права власника надр, у межах, визначених Конституцією й законами України. I в той же час забезпечують громадський контроль діяльності органів державної влади та органами місцевого самоврядування. Такий комплексний і системний підхід до ролі інститутів громадянського суспільства веде до посилення їх впливу на прийняття суспільно-важливих рішень у сфері використання надр, а також охорони надр від неправомірних посягань з боку держави та інших суб'єктів. Цей підхід запропоновано закріпити шляхом доповнення статті 13 Конституції України таким положенням: „Громадянське суспільство і держава в Україні є рівними партнерами в забезпеченні та захисті прав Українського народу як власника землі, ii надр, водних та інших природних ресурсів“.

Ключові слова: громадянське суспільство, принцип антропокосмізму, використання та охорона надр, природні ресурси

\section{Гражданское общество как субъект формирования государственной политики в сфере использования и охраны недр}

\author{
О. П. Васильченко, О. С. Лотюк, Н. Ю. Гуть
}

Киевский национальный университет имени Тараса Шевченко, г. Киев, Украина, e-mail: mfkoorg@gmail.com

Цель. Раскрыть особенности конституционных принципов паритетного партнерства гражданского общества и государства в процессе формирования государственной политики в сфере использования и охраны недр как объектов собственности украинского народа. Провести анализ взаимодействия гражданского общества и государства, определить контрольные функции институтов гражданского общества в сфере использования недр. Определить формы участия и контроля институтов гражданского общества в сфере использования и охраны недр.

Методика. Авторы использовали структурнофункциональный метод, а также сравнительно-правовой, историко-ретроспективный, формальнодогматический, конкретно-социологический методы. Авторы подчеркивают необходимость использования институционального метода исследования.

Результаты. Авторы рассмотрели развитие гражданского общества в Украине в начале XXI столетия и пришли к выводу, что оно происходит на основе существенно модернизированной системы конституционных ценностей. Каждая новая победа гражданского общества над бездеятельностью органов государственной власти сопровождается новыми принципами взаимодействия гражданского общества и власти. Предложено в основу государственной политики в сфере использования и охраны недр заложить принцип антропокосмизма, который в современной науке трансформировался в парадигму Ментальной Вселенной. В соответствии с принципом антропокосмизма государство должно действовать исключительно во благо человека будущего, пу- тем всестороннего обеспечения приоритета его прав, свобод и законных интересов в процессе деятельности публичной администрации. Собственность, а именно, недра, не могут быть использованы во вред человеку и обществу. Авторы определили, что в основе предоставления контрольных полномочий институтам гражданского общества положена возможность их влияния на государство с целью защиты законных интересов народа как собственника недр.

Научная новизна. Разработана система форм участия институтов гражданского общества в сфере использования и охраны недр. К формам участия отнесены: обращения граждан, подготовка и инициирование принятия или отмены нормативно-правового акта, проведение мирных собраний, митингов с целью влияния на принятие решений уполномоченными органами публичной администрации, осуществление профессионального представительства интересов общественности в органах публичной власти. Выделены основные формы контроля гражданского общества и его институтов органов государственной власти и органов местного самоуправления: проведение экспертизы эффективности принятых решений публичной администрацией; образование совместных с публичной администрацией консультативносовещательных и экспертных органов, комиссий с целью учета общественного мнения при формировании государственной политики в сфере использования и охраны недр; предоставление органам публичной администрации экспертных предложений.

Практическая значимость. Использование полученных результатов позволяет определить эффективные формы участия и контроля гражданского общества и его институтов в процессе реализации прав собственника недр, а именно: владение, использования и распоряжения недрами. Институты гражданского общества от имени украинского народа осуществляют права собственника недр, в пределах, определенных Конституцией и законами Украины. И в тоже время обеспечивают общественный контроль деятельности органов государственной власти и органами местного самоуправления. Такой комплексный и системный подход к роли институтов гражданского общества ведет к усилению их влияния на принятие общественно-важных решений в сфере использования недр, а также охране недр от неправомерных посягательств со стороны государства и других субъектов. Этот подход предложено закрепить путем дополнения статьи 13 Конституции Украины следующим положением: „Гражданское общество и государство в Украине являются равными партнерами в обеспечении и защите прав Украинского народа как собственника земли, ее недр, водных и других природных ресурсов“.

Ключевые слова: гражданское общество, принцип антропокосмизма, использование и охрана недр, природные ресурсы

Рекомендовано до публікації докт. філос. наук О. В. Фатхутдіновою. Дата надходження рукопису 25.11.17. 